\title{
Improvement of Hair Growth in Mouse Skin by Application of Consciousness Energy Treated Test Item
}

\author{
Trivedi $\mathrm{MK}^{1}$ and Jana $\mathrm{S}^{2 *}$ \\ ${ }^{1}$ Trivedi Global, Inc., Henderson, Nevada, USA \\ ${ }^{2}$ Trivedi Science Research Laboratory Pvt. Ltd., Bhopal, Madhya Pradesh, India \\ *Corresponding author: Snehasis Jana, Trivedi Science Research Laboratory Pvt. \\ Ltd., Bhopal, Madhya Pradesh, India, Email: publication@trivedieffect.com
}

\section{Research article \\ Volume 3 Issue 3}

Received Date: November 21, 2018

Published Date: December 07, 2018

DOI: $10.23880 /$ cdoaj- 16000165

\section{Abstract}

The objective of this experiment was to study the effect of Biofield Energy Treated test item (1:1 ratio of a mixture of the Biofield Energy Treated herbal extracts of Phyllantus emblica and Eclipta alba) on the normal hair cycle of C57BL/6 mice after topical application. The test item was divided into two parts. One part was denoted as the untreated test item, without any Biofield Energy Healing Treatment, while the other part was defined as the Biofield Energy Treated test item, which received the Consciousness Energy Healing Treatment by a renowned Biofield Energy Healer, Mahendra Kumar Trivedi. Mice telogen skin was prepared and used as a test system in this experiment for the topical application of the test item. The study parameters like induction of anagen and melanogenesis using skin biopsy technique were used in this experiment for the assessment of hair growth phages. The experimental results showed that the untreated and Biofield Energy Treated groups exhibited $50 \%$ and $100 \%$, respectively of hair growth on dorsal clipped of skin after topical application of the test items. Besides, both the untreated and Biofield Energy Treated test items exhibited 100\% melanogenesis after biopsy analysis in mice skin at the end of experiment. Altogether, results envisaged that The Trivedi Effect ${ }^{\circledR}$ promotes hair growth as evident via increased an earlier anagen induction, hair growth, and melanogenesis than untreated test item. Henceforth, the Biofield Energy Healing (The Trivedi Effect ${ }^{\circledR}$ ) Treatment could be useful as a hair growth enhancer for various types of skin injuries and skin-related disorders like actinic keratosis, necrotizing fasciitis, sebaceous cysts, diaper rash, decubitus ulcer, eczema, seborrheic dermatitis, chickenpox, measles, warts, acne, etc.

Keywords: Biofield Energy Treatment; Consciousness Energy Healing; The Trivedi Effect ${ }^{\circledR} ;$ Telogen skin; Melanogenesis; Skin health

\section{Introduction}

Numerous endogenous hormones are known to act as a potent hair growth modulator such as $17 \beta$-estradiol, androgens, retinoids, thyroids, calcitriols, and glucocorticoids [1-4]. Among these, estrogen is widely used as an excellent hair growth promoter, it arrests murine pelage hair follicle (HF) in telogen stage $[5,6]$. 
Irregular growth of hair follicles leads to various anomalies like alopecia, androgenic alopecia (male pattern baldness), etc. While, androgenic alopecia can occurs in female also due to abnormal synthesis, metabolism, and signaling of androgen through androgen receptor [7]. A lots of research data reported some demerits of in vitro model of hair follicle growth compared to animal models, which is extensively used most of the researchers for the evaluation of hair growth [8-11]. Hence, based on the sufficient evidences on in vivo experiment over in vitro study, authors conducted this experiment in male C57BL/6 mice. Minoxidil, a potent hair growth enhancer is routinely utilized to treat hair loss without any severe adverse effects [12], hence minoxidil was chosen as reference standard in this experiment for the assessment of hair growth. In recent years, several scientific reports have revealed the useful effects of Biofield Energy Treatment, which have shown to enhance the immune function in case of cervical cancer patients via therapeutic touch [13], massage therapy [14], etc. Complementary and Alternative Medicine (CAM) therapies are now rising as preferred models of treatment, among which Biofield Therapy (or Healing Modalities) is one approach that has been reported to have several benefits to enhance physical, mental and emotional human wellness. However, as per the data of 2012 from the National Health Interview Survey (NHIS), which indicated that the highest percentage $(17.7 \%)$ of the Americans used dietary supplements as a complementary health approach as compared with other practices in past years. The National Center of Complementary and Integrative Health (NCCIH) has recognized and accepted Biofield Energy Healing as a CAM health care approach in addition to other therapies, medicines and practices such as natural products, deep breathing, yoga, Tai Chi, Qi Gong, chiropractic/osteopathic manipulation, meditation, massage, special diets, homeopathy, progressive relaxation, guided imagery, acupressure, acupuncture, relaxation techniques, hypnotherapy, healing touch, movement therapy, pilates, rolfing structural integration, mindfulness, Ayurvedic medicine, traditional Chinese herbs and medicines, naturopathy, essential oils, aromatherapy, Reiki, and cranial sacral therapy. Human Biofield Energy has subtle energy that has the capacity to work in an effective manner [15]. CAM therapies have been practiced worldwide with reported clinical benefits in different health disease profiles [16]. This energy can be harnessed and transmitted by the experts into living and non-living things via the process of Biofield Energy Healing. Biofield Energy Treatment (The Trivedi Effect ${ }^{\circledR}$ ) has been published in numerous peer-reviewed science journals with significant outcomes in many scientific fields such as cancer research $[17,18]$, microbiology $[19,20]$, skin health $[21,22]$, biotechnology $[23,24]$, pharmaceutical science [25-27], agricultural science [28-30], bone health [31-33], materials science $[34,35]$, improved bioavailability [36$38]$, nutraceuticals $[39,40]$, human health and wellness.

Based on the literature information and importance of Biofield Energy Healing Treatment on various fields, the authors sought to evaluate the impact of the Biofield Energy Treatment (The Trivedi Effect ${ }^{\circledR}$ ) on the test item (the 1:1 mixture of herbal extracts of Phyllantus emblica and Eclipta alba) for hair cells growth activity with respect to the assessment of different hair growth parameters like anagen induction in terms of hair growth score and melanogenesis using standard biopsy assay in male C57BL/6 mice.

\section{Materials and Methods}

\section{Chemicals and Reagents}

The positive control, minoxidil solution was purchased from Dr. Reddy's Laboratories Ltd., India. The 1:1 ratio of herbal extracts of Phyllantus emblica and Eclipta alba were obtained from M/s. Sanat Products Ltd., India. All the other chemicals used in this experiment were analytical grade procured from India.

\section{Experimental Animals}

Randomly breed male C57BL/6 mice body weight ranges between 22 to $25 \mathrm{gm}$ were used in this experiment. The animals were purchased from M/s. Vivo Bio Tech Ltd., Hyderabad, India. Animals were randomly distributed into four groups based on their body weights. They were kept separately in a sterilized polypropylene cages with stainless steel top grill having provision for holding pellet feed and drinking water bottle fitted with stainless steel sipper tube. The test facility is registered for breeding and experiment of animals with the Committee for the Purpose of Control and Supervision of Experiments on Animals (CPCSEA), Ministry of Environment and Forest, Govt. of India. Study was approved by Institutional Animal Ethics Committee and the husbandry conditions was maintained as per CPCSEA recommendations (IAEC No.: IAEC/41/502). All the procedures and protocols related to animal experiment were approved and followed by Institutional Animal Ethics Committee (IAEC). All the animals were housed under standard experimental conditions, with room temperature $\left(22 \pm 3{ }^{\circ} \mathrm{C}\right)$, relative humidity (30\% to $70 \%$ ). 


\section{Clinical Dermatology Open Access Journal}

\section{Experimental Design}

Animals were grouped into four different treatment groups. Group 1 was served as vehicle control, treated with 1:1 ratio of polyethylene glycol (PEG) and ethyl alcohol. Group 2 was defined as positive control (minoxidil solution). Group 3 was assigned as the untreated test item (mixture of herbal extracts) and group 4 defined as the Biofield Energy Treated test item (mixture of herbal extracts). The dose regimen for the test item treated group was thrice daily on topical application for total of 28 days. Positive control and vehicle were applied topically twice daily for the period of 22 and 28 days, respectively.

\section{Biofield Energy Healing Strategies}

The test item (a 1:1 mixture of herbal extracts of Phyllantus emblica and Eclipta alba) was used in this experiment for the assessment of hair growth in male C57BL/6 mice. The test item was divided into two parts. One part was considered as the untreated test item, where no Biofield Energy Treatment was given. Further, the untreated test item group was treated with "sham" healer for better comparison purpose. The "sham" healer did not have any knowledge about the Biofield Energy Healing Treatment. Second part of the test item was received Biofield Energy Healing Treatment (known as The Trivedi Effect ${ }^{\circledR}$ ) under laboratory conditions for $\sim 3$ minutes through Mahendra Kumar Trivedi's unique Biofield Energy Transmission process to the test item.
Biofield Energy Healer was located in the USA, while the test item was located in the research laboratory of Dabur Research Foundation, New Delhi, India. Biofield Energy Healer in this study did not visit the laboratory, nor had any contact with the test sample. After that, the Biofield Energy Treated and untreated test items were kept in a similar sealed conditions and used for the study as per the study plan.

\section{Clipping of Animals}

The telogen skin (look visually as a pink skin) of the test animals was exposed by gentle clipping of hair from

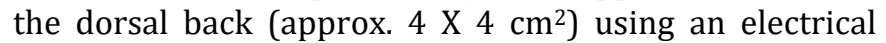
clipper one day before the application with the test item/positive control/vehicle.

\section{Body Weight}

Body weight of each animal was noted before application of the test items or positive control to the animals and then body weight was recorded once a week throughout the experimental period.

\section{Visual Melanogenesis}

The animals in each group were observed by visual examination of the color of the area of dorsal skin of the animal. The change of skin color was scored on a scale of 0-3 based upon the visual observations. The criterion of scoring the hair growth of animals is described in Table 1.

\begin{tabular}{|c|c|c|}
\hline S. No. & Observation & Hair Growth Score \\
\hline 1 & No hair growth, pink skin & 0 \\
\hline 2 & Skin color changes from pink to gray/light gray without visible hair growth & 0.5 \\
\hline 3 & $\begin{array}{c}\text { Skin color changes from gray/light grey to dark gray/black without visible hair } \\
\text { growth, indicating the onset of anagen }\end{array}$ & 1 \\
\hline 4 & Sparse hair growth & 1.5 \\
\hline 5 & Diffuse short hair growth & 2 \\
\hline 6 & Moderate hair growth & 2.5 \\
\hline 7 & Dense, normal coat hair & 3 \\
\hline
\end{tabular}

Table 1: Scoring of hair growth with grading criteria.

\section{Statistical Analysis}

Data were represented as mean \pm standard error of mean (SEM) and also as percentage of the respective parameters. For statistical analysis Sigma-Plot (version 11.0 ) was used as a statistical tool. Statistically significant values were set at the level of $p \leq 0.05$.

\section{Results and Discussion}

\section{General Health Status}

There were no signs of any distinct behavioral changes reaction to treatment or ill health observed in all the animals during the observation period treated with the test item. 


\section{Clinical Dermatology Open Access Journal}

\section{Body Weight}

Treatment with the test item did not lead to any adverse effects on body weight in any of the animals during the study i.e., body weight was gain on normal basis as like as vehicle control group (Data not shown).

\section{Anagen Induction and Hair Growth}

The animals treated with vehicle did not show any anagen induction or hair growth in any of the animal. The positive control, minoxidil sulphate led to anagen induction followed by 100\% hair growth (four out of four animals). The mean hair growth score of the untreated and Biofield Energy Treated test item groups are shown in Figure 1. The results showed that the untreated test item showed a visual anagen induction on dorsal clipped of skin in four animals out of four followed by hair growth in two animals out of four i.e., $50 \%$ after topical application. Moreover, the Biofield Energy Treated test item showed a visual anagen induction on dorsal clipped of skin followed by hair growth after topical application in four mice out of four i.e., 100\%. From Figure 1, it was observed that the Biofield Energy Treated test item group started an early hair growth (on day 9) compared to the untreated test item group (on day 12). Numerous literatures reported that mice telogen skin, a suitable model for the evaluation of different phases of skin development and process of hair growth [1,41-43]. In this context, authors designed this study to see the effect of Biofield Energy Healing Treatment on hair follicles growth and development. Overall, there was an improvement of hair follicle growth in the Biofield Energy Treated test item group as compared to the untreated test item group, which could be due to the effect of Consciousness Energy Healing Treatment by renowned Biofield Energy Healer (The Trivedi Effect ${ }^{\circledR}$ ).

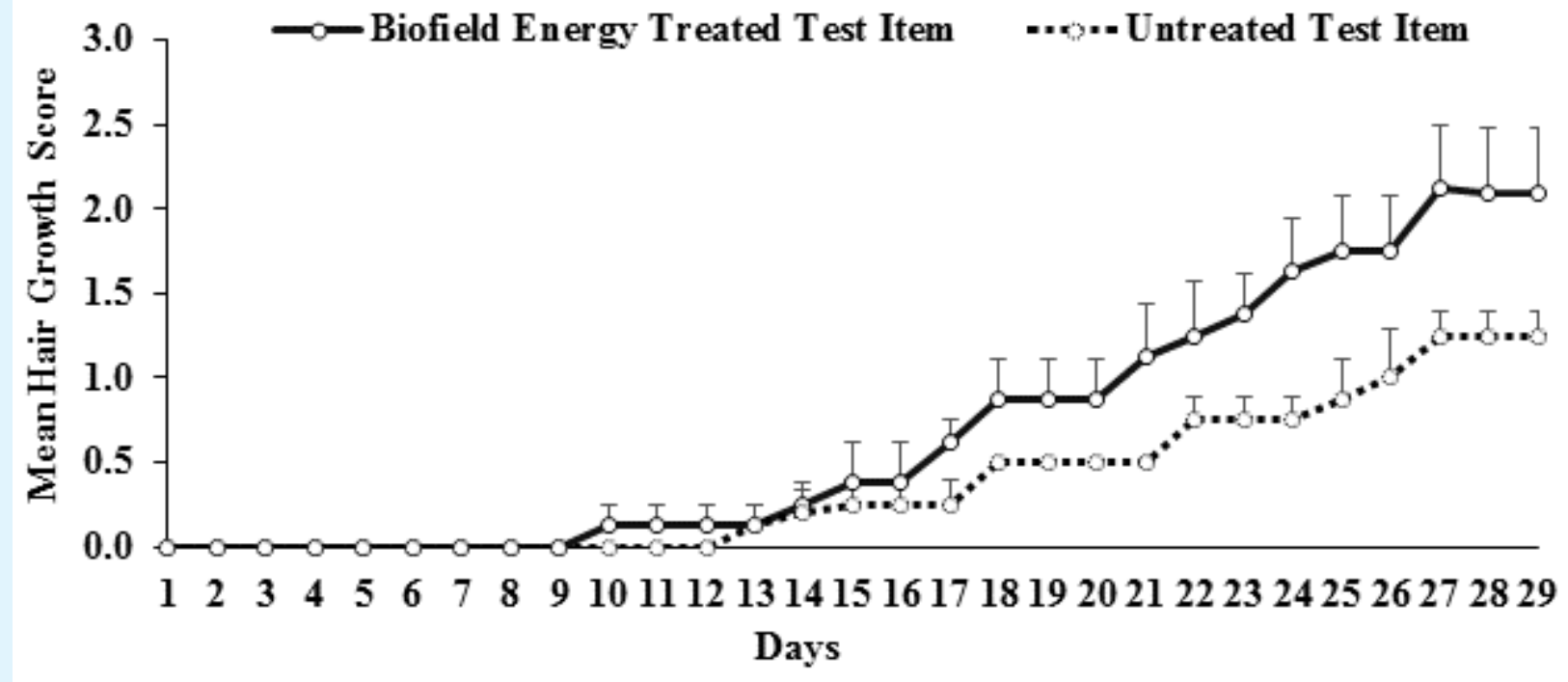

Figure 1: Effect of the untreated and Biofield Energy Treated test items (mixture of herbal extracts of Phyllantus emblica and Eclipta alba in 1:1 ratio) in male C57BL/6 mice. All the values were expressed as mean \pm standard error of mean (SEM). $n=4 / 5$.

\section{Visual Melanogenesis by Skin Biopsy}

Skin pigmentation is an important human phenotypic trait. Melanogenesis is a complex process in which melanin pigment is formed in melanosomes by melanocytes. The melanocyte cells activity is directly regulated by various physiological systems such as endocrine, immune, inflammatory and central nervous systems [44,45]. After disturbance of complex melanogenesis process leads to various types of pigmentation defects [46]. The results of melanogenesis after skin biopsy was recorded in the peeled skin of all the groups are depicted in Figure 2. There was no visual melanogenesis was recorded in the peeled skin of animals treated with vehicle. However, in the positive control group (minoxidil sulphate) showed 100\% melanogenesis in the peeled skin of four animals out of four animals. 
Moreover, both the untreated and Biofield Energy Treated test items groups exhibited $100 \%$ melanogenesis after topical treatment with the mixture of herbal extracts of
Phyllantus emblica and Eclipta alba in 1:1 ratio in male C57BL/6 mice (Figure 2).

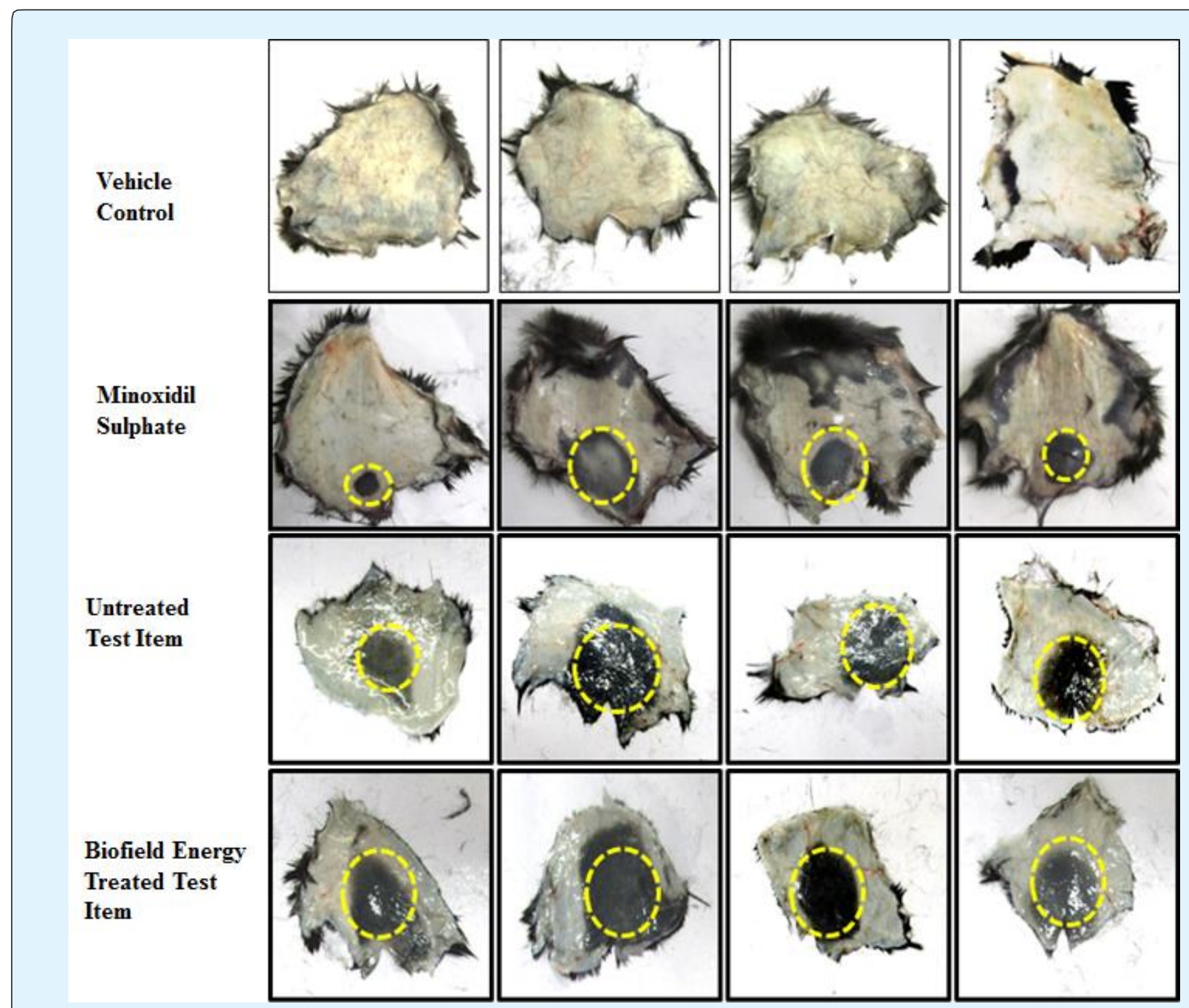

Figure 2: Representative biopsy photomicrograph of different treatment groups showing hair growth at the end of experiment in male C57BL/6 mice.

Overall, the Biofield Energy Treated test item remarkably improved the hair growth as compared with the untreated test item group. Based on the experimental results, it is envisaged that the improvement of hair cell growth and development could be due to the impact of The Trivedi Effect $^{\circledR}$ - Consciousness Energy Healing Treatment.

\section{Conclusions}

Based on the study findings, the results showed that after topical application of the Biofield Energy Treated test item led to faster anagen induction and faster rate of hair growth by $100 \%$ of the treated animals. Whereas, the animal treated with the untreated test item led to anagen induction followed by hair growth in 50\% animals only, 
even at a slower rate compared to the Biofield Energy Treated group. Further, the untreated and Biofield Energy Treated test items exhibited 100\% melanogenesis after biopsy analysis compared to the vehicle control group. Hence, based on the current study, it can be concluded that treatment with Biofield Energy led to faster anagen induction and faster hair growth promotion efficacy as compared to the untreated test item group. In conclusion, The Trivedi Effect $^{\circledR}$ - Consciousness Energy Healing Treatment might act as an effective hair growth enhancer and it can be used as a complementary and alternative treatment for the prevention of various types of skinrelated disorders viz. necrotizing fasciitis, actinic keratosis, sebaceous cysts, diaper rash, decubitus ulcer etc. Besides, it might be useful to improve cell-to-cell communication, normal cell growth, cell differentiation, neurotransmission, cell cycling and proliferation, hormonal balance, skin health, immune and cardiovascular functions. Besides, it can also be utilized in organ transplants (for example kidney transplants, liver transplants and heart transplants), hormonal imbalance, aging, and various immune related disease conditions such as Ulcerative Colitis, Alzheimer's Disease, Dermatitis, Irritable Bowel Syndrome, Asthma, Hashimoto Thyroiditis, Pernicious Anemia, Sjogren Syndrome, Multiple Sclerosis, Aplastic Anemia, Hepatitis, Diverticulitis, Graves' Disease, Dermatomyositis, Diabetes, Myasthenia Gravis, Parkinson's Disease, Atherosclerosis, Systemic Lupus Erythematosus, stress, etc. with a safe therapeutic index to improve overall health, and Quality of Life.

\section{Acknowledgements}

Authors gratefully acknowledged to Trivedi Global, Inc., Trivedi Science, Trivedi testimonials and Trivedi master wellness for their support. In addition, authors are thankful for the support of Dabur Research Foundation for conducting this study.

\section{References}

1. Paus R, Handjiski B, Czarnetzki BM, Eichmüller $\mathrm{S}$ (1994) A murine model for inducing and manipulating hair follicle regression (catagen): Effects of dexamethasone and cyclosporin A. J Invest Dermatol 103(2): 143-147.

2. Paus R, Schilli MB, Handjiski B, Menrad A, Henz BM, et al. (1996) Topical calcitriol enhances normal hair regrowth but does not prevent chemotherapy- induced alopecia in mice. Cancer Res 56(19): 44384443.

3. Stenn KS, Paus R, Dutton T, Sarba B (1993) Glucocorticoid effect on hair growth initiation: A reconsideration. Skin Pharmacol 6(2): 125-134.

4. Randall VA, Thornton MJ, Hamada K, Redfern CP, Nutbrown M, et al. (1991) Androgens and the hair follicle. Cultured human dermal papilla cells as a model system. Ann NY Acad Sci 642: 355-375.

5. Oh HS, Smart RC (1996) An estrogen receptor pathway regulates the telogen-anagen hair follicle transition and influences epidermal cell proliferation. Proc Natl Acad Sci USA 93(22): 12525-12530.

6. Smart RC, Oh HS, Chanda S, Robinette CL (1999) Effects of $17 \beta$-estradiol and ICI 182780 on hair growth in various strains of mice. J Investig Dermatol Symp Proc 4(3): 285-289.

7. Crabtree JS, Kilbourne EJ, Peano BJ, Chippari S, Kenney T, et al. (2010) A mouse model of androgenetic alopecia. Endocrinology 151(5): 23732380.

8. Matsuzaki T, Yoshizato K (1998) Role of hair papilla cells on induction and regeneration processes of hair follicles. Wound Repair Regen 6(6): 524-530.

9. Kondo S, Hozumi Y, Aso K (1990) Organ culture of human scalp hair follicles: Effect of testosterone and oestrogen on hair growth. Arch Dermatol Res 282(7): 442-445.

10. Chase HB, Rauch H, Smith VW (1951) Critical stages of hair development and pigmentation in the mouse. Physiol Zool 24(1): 1-8.

11. Paus R, Stenn KS, Link RE (1989) The induction of anagen hair growth in telogen mouse skin by cyclosporine A. Administration Lab Invest 60(3): 365369.

12. Vesoulis ZA, Attarian SJ, Zeller B, Cole FS (2014) Minoxidil-associated anorexia in an infant with refractory hypertension. Pharmacotherapy 34(12): e341-e344.

13. Lutgendorf SK, Mullen-Houser E, Russell D, Degeest K, Jacobson G, et al. (2010) Preservation of immune function in cervical cancer patients during 


\section{Clinical Dermatology Open Access Journal}

chemoradiation using a novel integrative approach. Brain Behav and Immun 24(8): 1231-1240.

14. Ironson G, Field T, Scafidi F, Hashimoto M, Kumar M, et al. (1996) Massage therapy is associated with enhancement of the immune system's cytotoxic capacity. Int J Neurosci 84(1-4): 205-217.

15. Jain S, Hammerschlag R, Mills P, Cohen L, Krieger R, et al. (2015) Clinical studies of biofield therapies: Summary, methodological challenges, and recommendations. Glob Adv Health Med 4: 58-66.

16. Rubik B (2002) The biofield hypothesis: Its biophysical basis and role in medicine. J Altern Complement Med 8(6): 703-717.

17. Trivedi MK, Patil S, Shettigar H, Mondal SC, Jana S (2015) The potential impact of biofield treatment on human brain tumor cells: A time-lapse video microscopy. J Integr Oncol 4: 141.

18. Trivedi MK, Patil S, Shettigar H, Gangwar M, Jana $S$ (2015) In vitro evaluation of biofield treatment on cancer biomarkers involved in endometrial and prostate cancer cell lines. J Cancer Sci Ther 7: 253257.

19. Trivedi MK, Branton A, Trivedi D, Nayak G, Shettigar $\mathrm{H}$, et al. (2015) Antimicrobial susceptibility pattern, biochemical characteristics and biotyping of Salmonella paratyphi A: An impact of biofield treatment. Clin Microbiol 4: 215.

20. Trivedi MK, Branton A, Trivedi D, Nayak G, Mondal SC, et al. (2015) Antibiogram of biofield-treated Shigella boydii: Global burden of infections. Science Journal of Clinical Medicine 4: 121-126.

21. Kinney JP, Trivedi MK, Branton A, Trivedi D, Nayak G, et al. (2017) Overall skin health potential of the biofield energy healing based herbomineral formulation using various skin parameters. American Journal of Life Sciences 5: 65-74.

22. Singh J, Trivedi MK, Branton A, Trivedi D, Nayak G, et al. (2017) Consciousness energy healing treatment based herbomineral formulation: A safe and effective approach for skin health. American Journal of Pharmacology and Phytotherapy 2: 1-10.

23. Trivedi MK, Branton A, Trivedi D, Nayak G, Mondal SC, et al. (2015) Evaluation of antibiogram, genotype and phylogenetic analysis of biofield treated Nocardia otitidis. Biol Syst Open Access 4: 143.

24. Trivedi MK, Branton A, Trivedi D, Nayak G, Charan S, et al. (2015) Phenotyping and 16S rDNA analysis after biofield treatment on Citrobacter braakii: A urinary pathogen. J Clin Med Genom 3: 129.

25. Trivedi MK, Patil S, Shettigar H, Bairwa K, Jana S (2015) Spectroscopic characterization of biofield treated metronidazole and tinidazole. Med Chem 5(7): 340-344.

26. Trivedi MK, Patil S, Shettigar H, Bairwa K, Jana S (2015) Effect of biofield treatment on spectral properties of paracetamol and piroxicam. Chem Sci J 6: 98.

27. Trivedi MK, Branton A, Trivedi D, Shettigar H, Bairwa $\mathrm{K}$, et al. (2015) Fourier transform infrared and ultraviolet-visible spectroscopic characterization of biofield treated salicylic acid and sparfloxacin. Nat Prod Chem Res 3: 186.

28. Trivedi MK, Branton A, Trivedi D, Nayak G, Gangwar M, et al. (2016) Molecular analysis of biofield treated eggplant and watermelon crops. Adv Crop Sci Tech 4: 208.

29. Trivedi MK, Branton A, Trivedi D, Nayak G, Gangwar M, et al. (2015) Effect of biofield energy treatment on chlorophyll content, pathological study, and molecular analysis of cashew plant (Anacardium occidentale L.). Journal of Plant Sciences 3: 372-382.

30. Trivedi MK, Branton A, Trivedi D, Nayak G, Mondal SC, et al. (2015) Impact of biofield energy treatment on soil fertility. Earth Sciences 4:275-279.

31. Anagnos D, Trivedi K, Branton A, Trivedi D, Nayak G, et al. (2018) Influence of biofield treated vitamin $\mathrm{D}_{3}$ on proliferation, differentiation, and maturation of bone-related parameters in MG-63 cell-line. International Journal of Biomedical Engineering and Clinical Science 4: 6-14.

32. Lee AC, Trivedi K, Branton A, Trivedi D, Nayak G, et al. (2018) The potential benefits of biofield energy treated vitamin $\mathrm{d} 3$ on bone mineralization in human bone osteosarcoma cells (MG-63). International Journal of Nutrition and Food Sciences 7: 30-38.

33. Stutheit ME, Trivedi K, Branton A, Trivedi D, Nayak G, et al. (2018) Biofield energy treated vitamin D3: 


\section{Clinical Dermatology Open Access Journal}

Therapeutic implication on bone health using osteoblasts cells. American Journal of Life Sciences 6: 13-21.

34. Trivedi MK, Nayak G, Patil S, Tallapragada RM, Latiyal 0 , et al. (2015) Characterization of physical and structural properties of brass powder after biofield treatment. J Powder Metall Min 4(1): 134.

35. Trivedi MK, Nayak G, Patil S, Tallapragada RM, Latiyal O, et al. (2015) Evaluation of biofield treatment on physical and structural properties of bronze powder. Adv Automob Eng 4: 119.

36. Branton A, Jana S (2017) The influence of energy of consciousness healing treatment on low bioavailable resveratrol in male Sprague Dawley rats. International Journal of Clinical and Developmental Anatomy 3: 915.

37. Branton A, Jana S (2017) The use of novel and unique biofield energy healing treatment for the improvement of poorly bioavailable compound, berberine in male Sprague Dawley rats. American Journal of Clinical and Experimental Medicine 5: 138144.

38. Branton A, Jana S (2017) Effect of The biofield energy healing treatment on the pharmacokinetics of 25hydroxyvitamin D3 $\left[25(\mathrm{OH}) \mathrm{D}_{3}\right]$ in rats after a single oral dose of vitamin D3. American Journal of Pharmacology and Phytotherapy 2(1): 11-18.

39. Trivedi MK, Nayak G, Patil S, Tallapragada RM, Jana S, et al. (2015) Bio-field treatment: An effective strategy to improve the quality of beef extract and meat infusion powder. J Nutr Food Sci 5: 389.

40. Trivedi MK, Tallapragada RM, Branton A, Trivedi D, Nayak G, et al. (2015) Biofield treatment: A potential strategy for modification of physical and thermal properties of gluten hydrolysate and ipomoea macroelements. J Nutr Food Sci 5: 414.

41. Jiang H, Yamamoto S, Kato R (1995) Induction of anagen in telogen mouse skin by topical application of fk506, a potent immunosuppressant. J Investig Dermatol 104: 523-525.

42. Orasan MS, Bolfa P, Coneac A, Muresan A, Mihu C (2016) Topical products for human hair regeneration: A comparative study on an animal model. Ann Dermatol 28(1): 65-73.

43. Pi LQ, Lee WS, Min S (2016) Hot water extract of oriental melon leaf promotes hair growth and prolongs anagen hair cycle: In vivo and in vitro evaluation. Food Sci Biotechnol 25(2): 575-580.

44. Lin JY, Fisher DE (2007) Melanocyte biology and skin pigmentation. Nature 445(7130): 843-850.

45. Park HY, Kosmadaki M, Yaar M, Gilchrest BA (2009) Cellular mechanisms regulating human melanogenesis. Cell Mol Life Sci 66(9): 1493-1506.

46. Fistarol SK, Itin PH (2010) Disorders of pigmentation. J Dtsch Dermatol Ges 8(3): 187-201. 